UDK 330.322:339.92(477+061.1€C)-047.44

JEL Classifications: C13, F21, P45

Doi: $10.31767 /$ su. 4(83)2018.04.06

T. M. Bulakh,

PhD, Associate Professor,

Associate Professor, the Department of Economics and Management

of Foreign Economic Activity,

E-mail: rla799@ukr.net;

O. A. Ivashchenko,

$\mathrm{PhD}$, Associate Professor,

Head, the Department of Economics and Management

of Foreign Economic Activity,

E-mail: o.i.nasoa@gmail.com;

National Academy of Statistics, Accounting and Audit;

O. Ye. Lytvyn,

PhD, Associate Professor,

Associate Professor of Economics and Management Department,

Banking University,

E-mail:alling@ukr.net

\title{
The Evaluation of Investment Cooperation of Ukraine with EU Countries
}

The article investigates and evaluates the investment cooperation of Ukraine with the EU. The volume, structure and dynamics of investment flows between Ukraine and the European Union are analyzed. The main problems of cooperation between Ukraine and the EU are formed, in particular: the volume of foreign direct investment (FDI) in Ukraine from the EU is directed mainly to those sectors of the economy where it is possible quickly to make a profit (for example, in financial activities), while investment in priority sectors of the economy of Ukraine, aimed at a long-term growth, is insufficient. In addition, during the analysis of the investment market of Ukraine problematic aspects were found, such as: the existence of a tendency to invest in offshore zones, a low differentiation of foreign investors for donor countries and a sharp imbalance in the structure of FDI in the economy of Ukraine. The political instability, unpredictability of a state power, lack of independent judiciary (abuse of courts), corporate raiding, prosecution by tax authorities, shortcomings in the implementation of laws, delays and lack of transparency in VAT refund, corruption and the low level of property rights' protection demonstrate the inability to build long-term plans with EU member states.

Measures are proposed to improve investment cooperation between Ukraine and the EU in the context of deepening European integration processes, as follow: 1) bringing the strategy of attracting foreign investment in accordance with the needs of the country; 2) providing European investors with the necessary system support (for example, in business registration, attracting personnel); 3 ) creating the necessary conditions for the further implementation of the liberalization of the legal framework for the free movement of FDI in accordance with EU rules; 4) close cooperation with FDI donor countries; 5) providing conditions for improvement of technical and technological conditions of domestic enterprises; 6) production intensification on an innovative basis, etc.

Key words: investment cooperation, foreign direct investment, European Union, investment climate, European integration.

European integration aspirations of Ukraine are integral realities of our time for the state. In the process of integration, the issue of investment cooperation becomes particularly relevant because Ukraine can mobilize necessary funds in the European market, especially to ensure macroeconomic stability, scientific and technological development, thereby diversifying the sources of external borrowing [11].

Issues of investment cooperation of Ukraine and countries - members of the EU are analyzed in the works of many Ukrainian and foreign scholars: V. Balasso, A. Beets, V. Budkin, A. Filippenko, S. Fischer, E. Greipl, A. Grubelnik, V. Heyets, A. Kasich, L. Khomutenko, V. Kravtsov, A. Mazaraki,

(CT. M. Bulakh, O. A. Ivashchenko, O. Ye. Lytoyn, 2018
V. Movchan, L. Pobachenko, M. Porter, S. Smallwood, J. Stiglitz, T. Vlasyuk, D. Zaitsev and oth.

However, given the revival of investment flows and the relatively low level of the Ukrainian government's solutions to the problems hindering the inflow of FDI in the economy of Ukraine, the peculiarities of investment cooperation become more relevant every year and require more careful study.

The purpose of the article is to assess the investment cooperation of Ukraine with the EU countries, highlight the problems and develop recommendations for its improvement in the context of deepening European integration processes.

The flow of foreign investment is extremely important for Ukraine. Therefore, since 2010 in this area the following legal acts have been adopted, such as: 
1) July 1, 2010, the Law of Ukraine "On publicprivate partnership" was adopted [7], which laid the Foundation for stimulating the development of cooperation between the private and public sectors in order to attract investment in the country's economy and to improve the competitiveness of its economy as a whole;

2) In 2010 the State Agency for Investments and National Projects of Ukraine was established. Its purpose was to support foreign investors in the interaction with the executive and local authorities;

3) In 2010-2014 the program of economic reforms "Rich society, competitive economy, effective state" was adopted. The aim was the implementation of specific measures to improve the business climate, especially the improvement of the licensing system, administrative services, licensing, business opening and its liquidation, technical regulation, formation of customs procedures [2];

4) January 1, 2012 the Law of Ukraine "On preparation and implementation of investment projects on the principle of "single window", which allowed to simplify the procedure for obtaining services necessary for the further implementation of the investment project [9];

5) June 21, 2012 the Verkhovna Rada of Ukraine adopted a draft of the Law of Ukraine "On industrial parks", which defined the legal and organizational basis for the creation and operation of industrial parks in Ukraine [8];

6) May 24, 2012 the Verkhovna Rada of Ukraine adopted the Law of Ukraine "On amendments to some legislative acts of Ukraine concerning state registration of foreign investments". It was developed on the implementation of subparagraph 1 of paragraph 1 of the plan of measures on simplification of implementation procedures of foreign enterprises and enterprises with foreign investment activity in Ukraine. The purpose of the bill was to establish a clear legislation on the implementation of a state registration of foreign investments by the state registration authorities and its simplification by increasing the submission period of the investor's documents for the state registration of foreign investments up to 30 calendar days after their actual introduction; the in-

troduction of a mechanism for registration of foreign investment if the non-resident investor sold or somehow transferred the corporate rights of the Ukrainian enterprise to another legal entity or individual - to a non-resident; establishing the procedure for cancellation of the state registration of foreign investment in the case of withdrawal (repatriation) of foreign investments, as well as establishing a seven-day period during which the state registration bodies carried out such registration [4].

7) In March 3, 2017 the Law of Ukraine "On amendments to the Law of Ukraine "On investment activity" provided bringing the terminology in line with current legislation; the definition of the term "investment project" and the content of the constituent parts of the investment project, directions, ways and measures of state support and stimulation of investment activity, as well as the introduction of a state registration of investment projects/project (investment) proposals requiring government support and assessing their cost-effectiveness [6].

In May 23, 2017 the Law of Ukraine "On amendments to some legislative acts of Ukraine regarding the removal of barriers to attracting foreign investment" was adopted [5]. The purpose of the Law was to promote the attraction of foreign investments, in particular, by simplifying the procedures for issuing permits for the employment of foreigners and residence permits in Ukraine for foreigners and stateless persons who were founders and / or participants and / or beneficial owners (controllers) of a legal entity registered in Ukraine, etc.

At the same time, the analysis of the indicators of investment activity for the period 2012-2017 allowed us to state that in Ukraine there was a reduction in the growth rate of FDI. The total volume of FDI, made in Ukraine in 2017, amounted USD $48248.7 \mathrm{mln}$. At the same time, the volume of direct investments from the member states of the European Union amounted USD 27.5 bln in 2017. It constituted $70.2 \%$ of the total investment in Ukraine compared to USD $26.2 \mathrm{bln}$ or $69.9 \%$ on January 1, 2017 respectively. The investment was made into the Ukrainian economy (Table 1, [10]) by the countries of the world, which was almost two times less than in the period in 2012-2014 [10].

Table 1

\section{Dynamics of Direct Investment (equity) from the EU to the} Economy of Ukraine

(USD mln)

\begin{tabular}{|l|c|c|c|c|c|c|}
\hline \multirow{2}{*}{ Countries } & \multicolumn{7}{c|}{ The volume of direct investment } \\
\cline { 2 - 7 } & 2012 & 2013 & 2014 & 2015 & 2016 & 2017 \\
\hline Total EU countries & 39268,9 & 41132,3 & 41032,8 & 31046,9 & 26405,6 & 27465,5 \\
\hline Cyprus & 12700,8 & 15907,7 & 17725,6 & 12769,4 & 10239,5 & 10008,6 \\
\hline Netherlands & 9323,8 & 8727,6 & 9007,5 & 6986,7 & 6184,7 & 6292,9 \\
\hline Great Britain & 2536,4 & 2496,9 & 2768,2 & 2153,4 & 1790,3 & 2169,0 \\
\hline Germany & 5329,8 & 4496,3 & 2908,4 & 2105,2 & 1598,2 & 1792,6 \\
\hline
\end{tabular}


Continuation of Table 1

\begin{tabular}{|l|c|c|c|c|c|c|}
\hline France & 1993,1 & 1510,3 & 1520,5 & 1394,6 & 1305,4 & 1346,6 \\
\hline Austria & 2317,5 & 2476,9 & 2314,0 & 1648,7 & 1559,8 & 1265,9 \\
\hline Luxembourg & 488,9 & 559,5 & 555,8 & 398,8 & 363,9 & 942,3 \\
\hline Hungary & 678,5 & 684,3 & 685,9 & 593,2 & 614,9 & 796,0 \\
\hline Poland & 834,3 & 897,2 & 819,8 & 808,6 & 758,3 & 815,5 \\
\hline Sweden & 1141,9 & 1084,4 & 439,3 & 360,2 & 328,9 & 353,6 \\
\hline Other EU countries & 1923,9 & 2291,2 & 2287,8 & 1828,1 & 1661,7 & 1682,5 \\
\hline
\end{tabular}

Despite the fact that the EU countries are topleading in the list of FDI investors into the Ukrainian economy, the structure of such investments is not enough to improve the European integration of Ukraine. Thus, $78.6 \%$ of investments are from four EU countries. Among the main investors are such countries as: Cyprus - USD 10.0 bln (36.4\% of the total investment from the EU), the Netherlands USD 6.3 bln (22.9\%), the UK - USD 2.2 bln (7.9\%), Germany - USD 1.8 bln (Fig. 1, [10]). Significant amounts of direct investment from EU countries are concentrated in industrial enterprises (25.4\%).

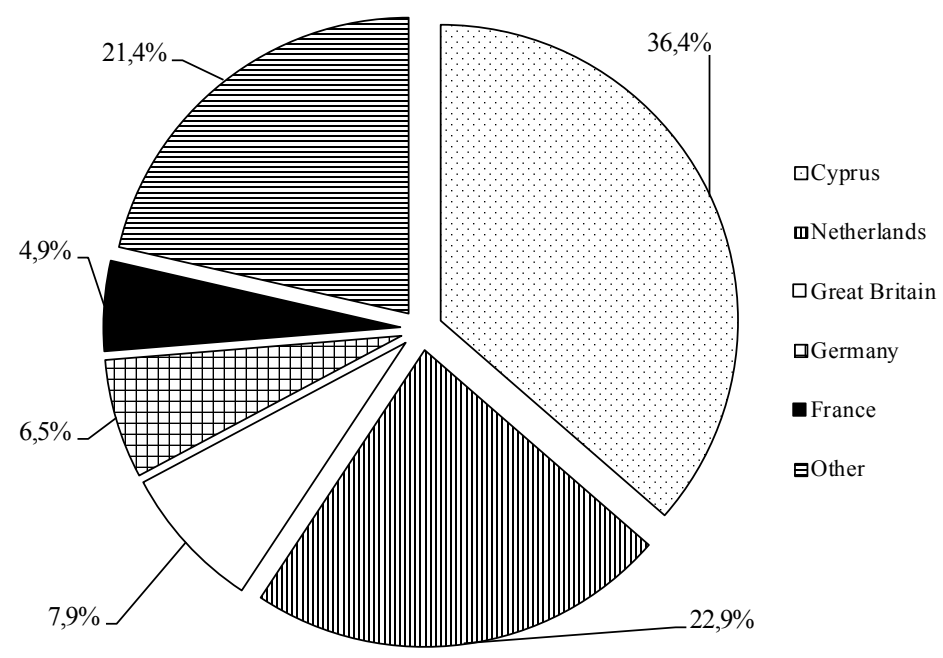

Fig. 1. Structure of FDI in the Economy of Ukraine from the EU in 2017

In general, it is accumulated $27.4 \%$ of direct of vehicles and motorcycles; $9.7 \%$ - in organizations investment in financial and insurance institutions; engaged in real estate transactions (Fig. 2, [10]). $14.6 \%$ - in the wholesale and retail trade, repairing

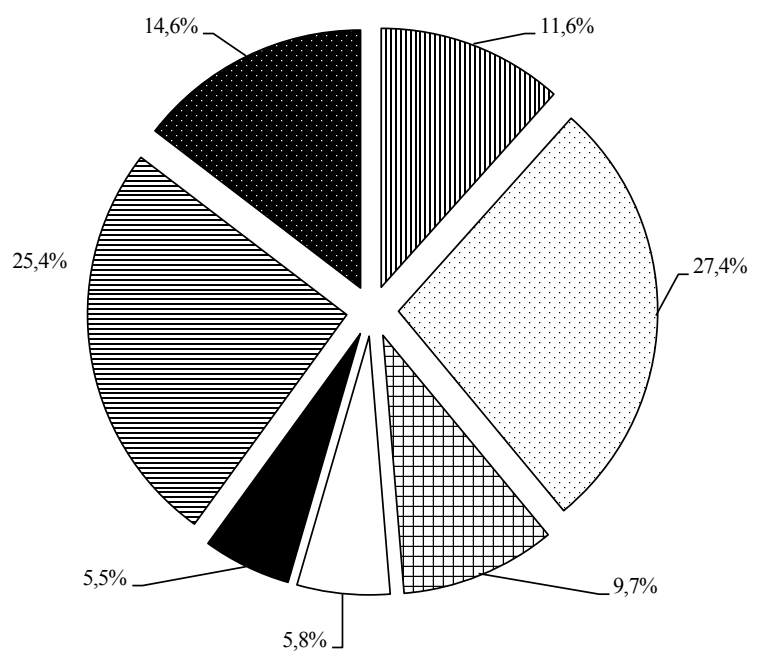

$\square$ Other activities

$\square$ Financial and insurance activities

$\square$ Real estate transactions

$\square$ Professional, scientific and technical activities

- Information and telecommunications

$\square$ Industry

$\square$ Wholesale and retail trade, repair of motor vehicles and motorcycles

Fig. 2. Structure of FDI in the Economy of Ukraine by Type of Economic Activity in 2017 
The structure of FDI was dominated in the industry by investments of the companies registered in Cyprus (24.3\%), the Netherlands (19.3\%), Germany (10.5\%), Switzerland $(9.2 \%)$, the UK (5.3\%), Austria (2.7\%) and Poland (2.7\%) at the end of 2017. Analyzing FDI of enterprises for the supply of electricity, gas, steam and air conditioning, it should be noted that $47.2 \%$ of FDI was made from Singapore, $36.1 \%$ - Cyprus and 6.5\% - from Belize. Similarly, analyzing direct investment in the extractive industry, it should be noted that at the end of 2017 , the structure of foreign income was dominated from Switzerland (45.6\%), the Netherlands (32.8\%), Cyprus (12.2\%) and the UK (1.5\%). Analyzing the FDI of processing industry companies, it should be noted that $26.3 \%$ of direct investment were made from Cyprus, $17.6 \%$ - the Netherlands, 13\% Germany, 6\% - the UK and others.

The FDI from the Netherlands (26.0\%), Cyprus (21.8\%) and the UK (10.9\%) was predominant in food, beverage and tobacco enterprises. The textile production, production of clothing, leather, leather goods and other materials were mainly represented by direct investments from Germany (27.1\%), Denmark (26.1\%) and Italy (12.3\%). The FDI from Cyprus (31.6\%), Austria (11.6\%) and Switzerland (11.4\%) was concentrated in the wood, paper and printing industries. The production of coke and refined petroleum products was represented by direct investments from Cyprus (86.8\%), the Netherlands (10.4\%) and the UK (1.1\%).

Chemical and chemical enterprises attracted $36.9 \%$ from Cyprus, 36.6\% - the Netherlands and $8.4 \%$ from France. Cyprus (44.5\%), the Virgin Islands (21.8\%) and the UK (9.1\%) dominated in the FDI structure for the production of basic pharmaceutical products and pharmaceuticals. The enterprises for producing rubber and plastic products, other nonmetallic mineral products mainly attracted direct investment from Cyprus (25\%), Germany (22.5\%) and the Netherlands (15.7\%).

The metallurgical production, production of finished metal products, in addition to the production of machinery and equipment, represented mainly FDI from Germany (37\%), Cyprus (32.2\%) and the Netherlands (10.7\%). In addition, to repair and installation of machinery and equipment, direct investments concentrated mainly from Korea (18.1\%), Germany (12.2\%) and Cyprus (11.1\%). The production of furniture, repair and installation of machinery and equipment represented mainly FDI from Cyprus (21.7\%), the UK (15.5\%) and Poland (14.1\%). The water supply, sewerage, waste management were represented from the UK (40.3\%), Cyprus (15,6\%) and Austria (13,3\%).

Nowadays the development of engineering is strategically important for Ukraine. The pace of development of this industry should exceed the overall growth rate of industrial production, creating conditions for structural and innovative restructuring and technical re-equipment of all sectors of the economy. The volume of FDI in machine-building enterprises, despite a slight increase in monetary terms, remains extremely low. The share of FDI in machine-building enterprises also remains at a low level [1].

Thus, the statistical analysis of the sectoral FDI structure into the economy of Ukraine by the EU confirms the assumption that the purpose of investment for many foreign investors is to use the Ukrainian market for quick profits. This is evident by the relatively high share of financial activities (27.4\%) and domestic trade (14.6\%), because these industries, without linking the company's funds, allow making a profit through a rapid turnover. At present, FDI in agriculture (the least promising component of the food industry with relatively quick profits) has not been received [3].

However, although the structure of FDI is still imperfect and meets the interests of foreign investors to get a quick profit than the strategic interests of Ukraine. However, there are quite positive trends in FDI structure that indicate the possibility of a certain final agreement of the interests of investors and the national economy. At the same time, there is a slight increase in FDI in the metalworking, transport and communication sectors - the strategic sectors of the Ukrainian economy.

While comparing the volume of investment to Ukraine with other countries, it is possible to find a significant difference among them. In 2017 Ukraine's FDI into the EU amounted USD 6.1 bln or $96.1 \%$ of the total investment from Ukraine (01.01.2017 USD $6.1 \mathrm{bln})$ [10]. In this case, foreign investment in the country's economy exceeded the volume of FDI from Ukraine by 4.5 times. However, this phenomenon was twofold, because the decrease in the ratio of investments in both directions indicated the development of the domestic economy, which was gaining momentum and began to manifest itself in the foreign investment activity. At the same time the decrease if the investment attractiveness of Ukraine was evident [3].

The study of investment to the economies of the EU countries revealed that the main importers of Ukrainian investments were: Cyprus, Latvia, and Hungary. In general, USD 5.9 bln of the total volume of Ukrainian investments into EU countries were located in Cyprus in the field of professional, scientific and technical activities (Fig. 3, [10]). The second and third places were taken by Latvia and Hungary in terms of investment. 


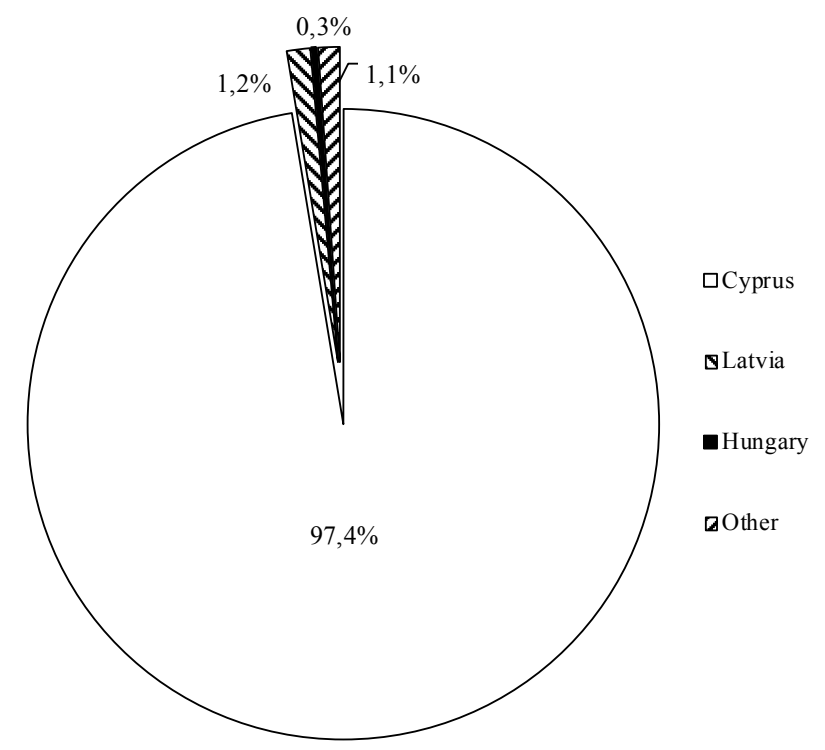

Fig. 3. Structure of Direct Investments from Ukraine to EU countries in 2017

The vast majority of Ukrainian investments in Cyprus were made by residents who carried out operations with the real estate, rent, engineering and services to entrepreneurs; in Latvia - financial institutions; in Hungary - trade enterprises, repairing of cars, household products and personal items.

Therefore, to sum up, the volume of FDI in Ukraine from the EU was directed mainly to those sectors of the economy where it was possibly to make a quick profit (for example, in financial activities). While the investment in the priority sectors of the economy of Ukraine, aimed at a long-term growth, was insufficient. In addition, during the analysis it was discovered such problematic aspects as: the existence of the propensity invested in offshore areas; a low differentiation of foreign investors in donor countries and a sharp imbalance in FDI structure in the Ukrainian economy. It caused the imbalances in the commodity and financial markets, the preservation of inefficient structure of production, the monopolization of certain strategic or socially important sectors of the economy, the misallocation of the resource and the resource base and production capacity.
The political instability, the unpredictability of a state power, the lack of an independent judiciary (misuse of courts), corporate raiding, the harassment by the tax authorities, shortcomings in the implementation of laws, delays in the VAT refunds, the corruption and low protection of property rights demonstrated the impossibility to build long-term plans with the countries members of the EU.

In our opinion, the main promising areas that could solve these problems are:

1) bringing the strategy of attracting FDI in accordance with the needs of the country;

2) providing European investors with the necessary system support (for example, in business registration, attracting personnel etc.);

3 ) creating the necessary conditions for the further implementation of the liberalization of the legal framework for the free movement of FDI in accordance with EU rules;

4) cooperating closely with FDI donor countries;

5 ) intensifying the production on an innovative basis, etc.;

6) providing the conditions for improvement of technical and technological condition of domestic enterprises.

\section{References}

1. Buriak, A. A. (2017). Investytsiine spivrobitnytstvo mizh Ukrainoiu ta YeS u promyslovosti: rehionalnyi rozriz [Investment cooperation between Ukraine and the EU in industry: regional aspect]. Naukovyi visnyk Mizhnarodnoho humanitarnoho universytetu - International Humanitarian University Herald. Economics and Management, 25-2, 30-33 [in Ukrainian].

2. Zamozhne suspilstvo, konkurentospromozhna ekonomika, efektyvna derzhava: Prohrama ekonomichnykh reform na 2010-2014 roky vid 02.06.2010 r. [A prosperous society, a competitive economy, an effective state: the Economic Reform Program for 2010-2014 of June 2, 2010]. zakon.rada.gov.ua. Retrieved from https://zakon.rada.gov.ua/laws/show/n0004100-10 [in Ukrainian].

3. Pobochenko, L. M., \& Bondarenko, A. V. (2011). Investytsiine spivrobitnytstvo Ukrainy z Yevropeiskym Soiuzom [Investment cooperation of Ukraine with the European Union]. Naukovyi visnyk Instytutu mizhnarodnykh vidnosyn NAU. Seriia: ekonomika, pravo, politolohiia, turyzm - Scientific Bulletin of the 
Institute of International Relations at NAU. Series: Economics, Lare, Political Science, Tourism, 1, № 1, 37-45 [in Ukrainian].

4. Pro vnesennia zmin do deiakykh zakonodavchykh aktiv Ukrainy schodo derzhavnoi reiestratsii inozemnykh investytsii: Zakon Ukrainy vid 24.05.2012 r. № 4835-VI [On Amendments to Certain Legislative Acts of Ukraine Regarding the State Registration of Foreign Investments: Law of Ukraine of May 24, 2012, No. 4835-VI].zakon.rada.gov.ua. Retrieved from https://zakon.rada.gov.ua/laws/show/4835-17 [in Ukrainian].

5. Pro vnesennia zmin do deiakykh zakonodavchykh aktiv Ukrainy schodo usunennia barieriv dlia zaluchennia inozemnykh investytsii: Zakon Ukrainy vid 23.05.2017 r. № 2058-VIII [On Amendments to Certain Legislative Acts of Ukraine on Elimination of Barriers to Attracting Foreign Investments: Law of Ukraine of May 23, 2017, No. 2058-VIII]. zakon.rada.gov.ua. Retrieved from https://zakon.rada.gov.ua/laws/ show/2058-19 [in Ukrainian].

6. Pro vnesennia zmin do Zakonu Ukrainy "Pro investytsiinu diialnist"” schodo derzhavnykh investytsiinykh proektiv: Zakon Ukrainy vid 23.03.2017 r. № 1981-VIII [On Amendments to the Law of Ukraine "On Investment Activity" concerning state investment projects: Law of Ukraine of March 23, 2017, No. 1981-VIII]. zakon.rada.goz.ua. Retrieved from https://zakon.rada.gov.ua/laws/show/1981-19 [in Ukrainian].

7. Pro derzhavno-pryvatne partnerstvo: Zakon Ukrainy vid 01.07.2010 r. № 2404-VI [On Public-Private Partnership: Law of Ukraine of July 1, 2010, No. 2404-VI]. zakon.rada.gov.ua. Retrieved from https://zakon. rada.gov.ua/laws/show/2404-17 [in Ukrainian].

8. Pro industrialni parky: Zakon Ukrainy vid 21.06.2012 r. № 5018-VI [On industrial parks: Law of Ukraine of June 21, 2012, № 5018-VI]. zakon.rada.gov.ua. Retrieved from https://zakon.rada.gov.ua/laws/ show/5018-17 [in Ukrainian].

9. Pro pidhotovku ta realizatsiiu investytsiinykh proektiv za pryntsypom "yedynoho vikna': Zakon Ukrainy vid 21.01.2010 r. № 2623-VI [On the preparation and implementation of investment projects on a one-stop-shop principle: Law of Ukraine of January 21, 2010, No. 2623-VI]. zakon.rada.gov.ua. Retrieved from https://zakon.rada.gov.ua/laws/show/2623-17 [in Ukrainian].

10. Spivrobitnytstvo mizh Ukrainoiu ta krainamy YeS u 2017: Statystychnyi zbirnyk [Cooperation between Ukraine and EU countries in 2017: Statistical collection]. (2018). ukrstat.org. Retrieved from http:// ukrstat.gov.ua/druk/publicat/kat_u/2018/zb/06/zb_ES_2017.pdf [in Ukrainian].

11. Khomutenko, L.I., \& Khmelyk, L. I. (2015). Tendentsii ta perspektyvy investytsiinoho spivrobitnytstva Ukrainy z Yevropeiskym Soiuzom [Trends and Prospects of Investment Cooperation of Ukraine with The European Union]. Hlobalni ta natsionalni problemy ekonomiky - Global and National Problems of the Economy 5, 99-103. Retrieved from http://global-national.in.ua/archive/5-2015/21.pdf [in Ukrainian].

\section{T. М. Булах,}

кандидат економічних наук, доцент,

доцент кафедри економіки та менеджменту

зовнішньоекономічної діяльності;

О. А. Іващенко,

кандидат економічних наук, доцент,

завідувач кафедри економіки та менеджменту

зовнішньоекономічної діяльності;

Національна академія статистики, обліку та аудиту;

О. Є. Литвин,

кандидат економічних наук, доцент,

доцент кафедри економіки та менеджменту,

ДВНЗ "Університет банківської справи"

\section{Оцінка інвестиційного співробітництва України з країнами ЄС}

Досліджено та оцінено інвестиційне співробітництво України з країнами ЄС. Проаналізовано обсяги, структуру та динаміку інвестиційних потоків між Україною та Європейським Союзом. Сформовано головні проблеми співпраці України з СС, ключовою з яких є така: надходження прямих іноземних інвестицій в Україну з ЄС спрямовані переважно ті галузі економіки, де можна швидко отримати прибуток (наприклад, у фінансову діяльність), тоді як інвестування пріоритетних галузей економіки України, націлене на довгострокове зростання, є недостатнім. Крім того, під час аналізу інвестиційного ринку України виявлені такі проблемні аспекти, як схильність до інвестування в офшорні зони, низька диференціація іноземних інвесторів за країнами-донорами та різкий дисбаланс у структурі надходжень прямих іноземних інвестицій в економіку України. Економічна нестабільність, непередбачуваність державної політики, відсутність незалежної судової влади (зловживання судів), корпоративне рейдерство, переслідування з боку податкових органів, недоліки в імплементації зако- 
нів, затримки і непрозорість повернення ПДВ, корупція та низький рівень захисту прав власності гальмують процеси побудови довготривалих планів співробітництва з країнами-членами ЄС.

Запропоновано заходи щодо покращення інвестиційного співробітництва України з країнами ЄС в частині поглиблення євроінтеграційних процесів: приведення стратегії залучення іноземних інвестицій у відповідність до потреб країни; забезпечення європейських інвесторів необхідною системною підтримкою, наприклад у реєстрації бізнесу, залученні персоналу тощо; створення необхідних умов для подальшої імплементації та лібералізації положень нормативно-правової бази щодо вільного переміщення ПІІ згідно з нормами ЄС; налагодження тіснішої співпраці з країнами - донорами прямих іноземних інвестицій; створення умов для покращення технічного та технологічного стану вітчизняних підприємств; інтенсифікація виробництва на інноваційній основі та ін.

Ключові слова: інвестииійне співробітництво, прямі іноземні інвестииії, Європейський Союз, інвестиційний клімат, євроінтегращіл.

\section{T. Н. Булах,}

кандидат экономических наук, доцент,

доцент кафедры экономики и менеджмента

внешнеэкономической деятельности;

\section{О. А. Иващенко,}

кандидат экономических наук, доцент

заведующий кафедрой экономики и менеджмента

внешнеэкономической деятельности;

Национальная академия статистики, учета и аудита;

О. Е. Литвин,

кандидат экономических наук, доцент,

доцент кафедры экономики и менеджмента,

ГВУЗ “Университет банковского дела"

\section{Оценка инвестиционного сотрудничества Украины со странами ЕС}

Исследовано и оценено инвестиционное сотрудничество Украины со странами ЕС. Проанализированы объемы, структура и динамика инвестиционных потоков между Украиной и Европейским Союзом. Сформированы главные проблемы сотрудничества Украины с ЕС, среди которых экономическая нестабильность, непредсказуемость государственной политики, отсутствие независимой судебной власти, непрозрачность деятельности налоговых органов, недостатки в осуществлении законов, коррупция и низкий уровень защиты прав собственности. Предложены мероприятия по улучшению инвестиционного сотрудничества Украины со странами ЕС в контексте углубления евроинтеграционных процессов.

Ключевые слова: инвестиционное сотрудничество, прямые иностранные инвестиции, Европейский Союз, инвестиционный климат, евроинтеграция.

Bibliographic description for quoting:

Bulakh, T. M., Ivashchenko, O. A., Lytvyn, O. Ye. (2018). The Evaluation of Investment Cooperation of Ukraine with EU Countries. Statystyka Ukrainy - Statistics of Ukraine, 4, 50 -56 [in English].

Бібліографічний опис для цитування:

Булах Т. М., Іващенко О. А., Литвин О. Є. Оцінка інвестиційного співробітництва України з країнами ЄС (публікується англійською мовою) // Статистика України. 2018. № 4. С. 50-56. 